\title{
10 Like, Share and Comment! The Use of Facebook by Public Libraries and Museums: A Case Study from Tromsø, Norway
}

\section{Introduction}

Historically, libraries, archives and museums (LAMs) have been perceived as institutions providing infrastructure for an open and enlightened public discourse. While Norwegian public libraries are regulated by law that focuses on libraries being providers of knowledge and agents of popular enlightenment as well as local meeting places and arenas for debate, ${ }^{1}$ the Norwegian museum sector is governed by relatively general and open political signals about the role of museums in society. Nevertheless, diversity, inclusion, and dialogue are important key words for both institutions. ${ }^{2}$ In addition, public libraries and museums are also supposed to keep up with technological development, not only to digitize their own collections but also to offer digital services to the public. ${ }^{3}$ Most public libraries and museums do not only have official webpages offering information about their services and self-services, but are also present on social media platforms like Facebook, Twitter, Instagram or YouTube.

This article investigates how three institutions in Troms $\emptyset$ (the main branch of the Troms $\varnothing$ public library and two museums) are using Facebook. By analyzing the frequency of posts, their content and the user participation created, I seek to

1 See https://lovdata.no/dokument/NL/lov/1985-12-20-108, accessed September 192018.

2 See for instance the Norwegian government's white paper number 49 (2008-2009). Framtidas museum - Forvaltning, forskning, formidling, fornying, 102: "Museene skal gi både kunnskap og opplevelse. De skal være tilgjengelige for alle og være relevante og aktuelle samfunnsinstitusjoner som fremmer kritisk refleksjon og skapende innsikt. En aktiv formidling er derfor viktig både i et demokratiperspektiv og i et allment kulturperspektiv" (The museums will provide both knowledge and experience. They should be accessible to all and be relevant community institutions that promote critical reflection and creative insight. Active dissemination is therefore important both in a democracy perspective and in a general cultural perspective (my translation)). 3 See for instance the Norwegian government's white paper number 24 (2008-2009) about the digital preservation and dissemination of cultural heritage, and white paper number 27 (20152016) about the use of information technology to make everyday life easier. Public libraries are supposed to increase the digital skills of the inhabitants, and thus contribute to increased digital user participation (Kommunal- og moderniseringsdepartementet (2015), 116-117). 
answer the following questions: what type of posts are the institutions posting? What type of posts are the ones that engage users? What type of user engagement is most common? What similarities and differences can be observed between the three institutions? By answering these questions, I hope to show how the three institutions and their followers use Facebook. I have chosen to focus on the institutions' Facebook pages because Facebook is by far the most popular social media platform with about $64 \%$ of the Norwegian population having a Facebook account in 2017. All three institutions are in addition to Facebook also present on other social media platforms like Instagram, Twitter or Flickr, but the highest number of followers is on Facebook.

\section{Facebook in Relation to Public Libraries and Museums}

As pointed out by Carlsson, "the body of academic research studying the use of social web in public libraries" (Carlsson 2015, 632) is growing. Investigated aspects are the strategies for social media use, the perception of stakeholders, best practices, and including how libraries advertise their services through Facebook. One of the latest contributions researches public library programs through Facebook events (Mathiasson and Jochumsen 2019). Nevertheless, "empirical work that explores the consequences of social web for public libraries in situ" (Carlsson 2015, 644 ) is missing. There are some case studies from different countries about museums' use of social media, ${ }^{4}$ whereas Camarero et al. "analyze the communication strategies of 240 fan pages and the effect on engagement indicators at a fan page level” (2018, 1120). Capriotti and Losada-Díaz evaluate whether art museums are using Facebook "as a tool for dialogic communication with their publics" (2018, 644) and if the various resources offered by social media platforms are used to encourage interaction with the publics. There are almost no studies about Norwegian museums ${ }^{5}$ or Norwegian public libraries and their use of social media and no comparisons between different institutions in whether they succeed in reaching out to potential audiences by using social media or not. This article therefore presents the results from a case study where the Facebook pages of three institutions are investigated. In order to compare these three Facebook pages, I have analyzed the first six months of 2018 (January 1 until June 30) to find the total

\footnotetext{
4 See Kidd 2011, 2016 for the UK; Badell 2015 for Catalan museums; and Lazaretti et al. 2015 for the Museum of Natural History of Florence.

5 Jørgensen 2011 presents a case study about NTNU Museum of Natural History in Trondheim, Norway and its exploration of web 2.0 technologies to communicate with museum visitors with a focus on a science blog and a science wiki.
} 
number of posts, the content of the posts, and the number and kind of user involvement (like, share, comment). While the total number of posts can give us an impression on the institutions' presence and activity on FB, the content of the post will tell us about the kind of information the institutions are disseminating through FB. We can assume that public libraries and museums are using social media to disseminate information and to communicate with their audiences. As stated in Camarero et al., "measuring organizations' communication performance in SNS and level of user engagement is by no means an easy task" $(2018,1120)$. Researchers have proposed different metrics. I will in the following employ the "three consumer engagement dimensions" proposed by Camarero et al.: "popularity, generated content, and virality" $(2018,1120)$. While the number of "likes" can be related to a page's popularity, Facebook allows its members to not only be a visitor of a page, but also to become a content producer by commenting. Generated content can be seen as an indicator for the users' commitment; the number of reposts or shares can measure the virality of a post or page.

My analysis has not considered information on how the Facebook algorithm works and what consequences this might have for the visibility of posts on users' own walls. While studies like Camarero et al. have used analytical tools to analyze a large number of Facebook pages, my own analysis was conducted manually using Excel. As far as I could find there are no longer free analytical tools available, probably because Facebook's data access policy has changed lately (Camarero et al. 2018, 1130). I have used my own FB account and accessed the institutions' FB pages to register all posts during the analyzed six-month period. Therefore, this analysis is based on small numbers for only three institutions, but is nevertheless complete in the sense that all posts during that period are registered and not only posts that appeared on my own wall. The findings therefore might reveal some interesting tendencies for how public libraries and museums are using social media and how they succeed in engaging their audiences.

\section{A Short Presentation of the Institutions}

All three institutions are situated in Tromsø, a municipality with 76,649 inhabitants and a large number of tourists visiting each year. Troms $\varnothing$ public library and Perspektivet museum are located in the city center, while The Arctic University Museum of Norway (TMU) is located outside the city center and can be reached by bus or car. 


\section{Tromsø Public Library}

Troms $\emptyset$ public library is a popular institution in the heart of the city. The numbers reported for 2017 show that the library had 7.8 visits and 4.7 loans total per inhabitant. While the last number is slightly higher than the average number for Norway as a whole, the number of visits is almost double the average number for Norway. ${ }^{6}$ The library has an official webpage with self-service opportunities for patrons like searching the library database or managing loans, information about opening hours, current events, and contact information. Here we also find links to social media platforms the library is present on: Facebook, Flickr, Twitter, YouTube, and Instagram. ${ }^{7}$

\section{The Arctic University Museum of Norway (TMU)}

The museum was founded in 1872 and is North Norway's oldest research institution. In 1976 the museum was incorporated in the University of Tromsø. Today the museum is a conglomerate consisting of The Arctic University Museum of Norway, The Polar Museum, MS Polstjerna, and the Troms $\varnothing$ Arctic Alpine Botanical Garden. Each of these branches have their own webpages and social media appearance, some available in Norwegian and English. I will in the following only focus on The Arctic University Museum of Norway, which had 55,089 visitors in 2017 and 60,909 in 2018.

The museum's webpages (see https://uit.no/tmu) are part of the university's official webpages. Here we find information about exhibitions, collections, and research, outreach initiatives especially for schools, information about the employees, and latest news. On the page with contact information we find a telephone number and an e-mail-address as the only possibility for individual contact. At the top left hand side of the page we also find two icons of social media platforms: Facebook and Instagram. By clicking on these icons, we get forwarded to the museum's Facebook page and Instagram account.

\footnotetext{
6 These numbers are according to the statistics made available by the National Library of Norway (only in Norwegian), https://kunnskapsbase.bibliotekutvikling.no/statistikk/statistikk-fornorske-bibliotek/folkebibliotek/, accessed February 27, 2019.

7 See https://www.tromso.kommune.no/hjem.255743.no.html, accessed May 15, 2019. The information is available in Norwegian, Sami, and English.
} 


\section{Perspektivet Museum}

Perspektivet Museum is a foundation established in 1996. The scope and contents of the museum's collections reflect Troms $\varnothing$ and the surrounding community's history from the 1950s to today. The museum belongs to Norway's national museum network and also participates in networks for minorities and cultural diversity. One important goal for the museum is to be a part of conversations and debates about issues of today. ${ }^{8} 24,361$ persons visited the museum in 2017 and 29,534 in 2018. The growing number of tourists visiting Troms $ø$ might explain the growth in visitors, but also the number of events taking place at the museum has increased during that period. The museum has a webpage in Norwegian and English (https://www.perspektivet.no/en/) informing about exhibitions, collections, and contemporary documentations. Under the headline "About the museum" we can read about the museum's history and about the people employed at the museum. In addition to Facebook, the museum is also present on Instagram and Flickr.

\section{The Institutions' Presence on Facebook}

The number of people who like the Facebook page of an institution (by September 2019) compared to the number of inhabitants in the municipality can give an indication about the use of these pages. ${ }^{9}$ Compared to other public libraries and museums in municipalities with about the same number of inhabitants, the numbers for Troms $ø$ are about average (Table 10.1). It is impossible to know from the outside why people choose to like the FB page of an institution. We can nevertheless assume that people who for instance like the FB page of the Tromsø public library are users of the library or at least sympathetic to the institution. The number of people who like a FB page does not necessary tell anything about how involved or active these persons are on FB. However, a general observation is that the number of followers is much higher than of the people who like, share or comment on the page. Even large institutions like the Museum of Modern Art (MoMA) in NYC with over 2 million followers has not much user generated activity on its FB page. The same can be said for public libraries in large cities.

8 For more information see the museum's own presentation on its web page, https://www. perspektivet.no/en/about-the-museum/, accessed May 152019.

9 People who like a certain FB page do not need any geographical closeness to the institution. Tourists can like a FB page, as well as people who have a professional interest, for instance libraries or museums are other potential followers. 
Tab. 10.1: Number of people who like the Facebook pages

\begin{tabular}{lll}
\hline Institution & $\begin{array}{l}\text { Number of people who } \\
\text { like the FB page }\end{array}$ & $\begin{array}{l}\text { Number of inhabitants in } \\
\text { the municipality* }\end{array}$ \\
\hline Tromsø public library & 4.291 & 76.601 \\
TMU & 7.652 & 76.601 \\
Perspektivet museum & 2.108 & 76.601 \\
Fredrikstad public library & 4.360 & 82.206 \\
Østfoldmuseene & 7.665 & 82.206 \\
Drammen public library & 3.260 & 69.233 \\
Drammens museum & 3.959 & 69.233 \\
Sandnes public library & 2.958 & 77.959 \\
\hline
\end{tabular}

* These numbers are according to Statistics Norway, https://www.ssb.no/kommunefakta/ tromso, accessed September 42019.

The period analyzed is the first six months of 2018, from January 1 until June 30. Even if the time period studied is limited, the results (Table 10.2) indicate some interesting tendencies.

Tab. 10.2: Number of posts per month

\begin{tabular}{llllllll}
\hline & January & February & March & April & May & June & Total \\
\hline Tromsø public library & 21 & 25 & 24 & 24 & 17 & 22 & 133 \\
TMU & 21 & 30 & 38 & 19 & 21 & 22 & 151 \\
Perspektivet museum & 11 & 14 & 12 & 15 & 9 & 13 & 74 \\
\hline
\end{tabular}

While the university museum (TMU) has most posts during these six months (151), the library is not far behind with 133 posts in total. On average the library posts 22 posts each month and the university museum 25 . Perspektivet museum has only 74 posts during the period, a clearly lower number than the other two institutions, but the museum is still active on a regular basis with an average of 12 posts each month. TMU was most active on Facebook in February and March, while the other months have a stable number of posts (about 20). The same can be said about the Facebook presence of the public library: about 20 posts each month, with only May - a month with many holidays - having less posts.

These numbers indicate that all three institutions are present on Facebook on a regular basis during the period investigated. They are nevertheless less active than proposed by Capriotti and Losada-Díaz: "According to these reports, the adequate frequency of posting would be between 1 and 2 posts per day (around 
7 and 15 posts per week)" (Capriotti and Losada-Díaz 2018, 645). The numbers for the three Tromsø institutions are meanwhile in line with the authors' findings for museums' posting activity on Facebook that has a "low average of just over two posts per week [...]. Moreover, the average number of original posts of museums is even smaller" (Capriotti and Losada-Díaz 2018, 645), as we will see in the following analysis of the posts.

\section{Tromsø Public Library on Facebook}

In June 2019 4,392 persons followed the FB-page of the Tromsø public library. The number of followers is not especially high compared to the number of inhabitants, but distinctly higher than for other social media platforms the library is using. ${ }^{10}$

As mentioned above, the library posts on a regular basis on Facebook, between 17 and 25 posts each month, or 5.5 post per week. In order to analyze the posts, the text of each post, the number of likes, shares, and comments were registered in an Excel document. Seven categories were created: literature, event announcement, shared content, information, pictures, questions, and other. In the case of doubt, the most prominent theme was chosen; for instance book reviews published by newspapers and shared by the library were categorized as "literature" and not as "shared content".

Table 10.3 shows the number of posts per months by these categories.

A large part of the posts are events getting announced (45) and shared content (30). Posts about literature, either book reviews or suggestions for what to read, are - not surprisingly for a library - frequent. Only a few posts are formulated as questions to the patrons or as an invitation to contribute for instance by sending in a photo of one's own book shelf or asking children to make a drawing for the library. Only two of the posts ask for the patrons' opinion about literature. The large majority of posts therefore is simply informative, not trying to establish a conversation between the library and its followers.

Most of the posts - 85 out of 133 in total - have between zero and ten likes. Taking into consideration that almost 4,000 people liked the page in 2018 and were engaged in one way or another with the content of the page, this number suggests little user engagement and activity. Only very few posts seem to be much more popular. The three posts with most likes ${ }^{11}$ were also shared and commented

10 By June 2019 the library had 18 followers on Flickr, 680 on Twitter, 13 on YouTube and 1,649 on Instagram.

11 Screenshots of the library's Facebook posts were taken 26.6.2018. 
Tab. 10.3: Tromsø public library - number of posts by categories

\begin{tabular}{|c|c|c|c|c|c|c|c|c|}
\hline & $\begin{array}{l}\text { Number } \\
\text { of posts }\end{array}$ & $\begin{array}{l}\text { Litera- } \\
\text { ture }^{\text {a) }}\end{array}$ & $\begin{array}{l}\text { Event an- } \\
\text { nounce- } \\
\text { ment }\end{array}$ & $\begin{array}{l}\text { Shared } \\
\text { link/ } \\
\text { content/ } \\
\text { post }\end{array}$ & $\begin{array}{l}\text { Questions/ } \\
\text { wish for } \\
\text { response }\end{array}$ & $\begin{array}{l}\text { Infor- } \\
\text { mation b) }\end{array}$ & Pictures ${ }^{c)}$ & Other \\
\hline Jan & 21 & 1 & 10 & 7 & $1^{d)}$ & & 2 & \\
\hline Feb & 25 & 5 & 11 & 6 & & & 2 & $1^{e)}$ \\
\hline Mar & 24 & 4 & 6 & 5 & 2 & 5 & 2 & \\
\hline Apr & 24 & 4 & 9 & 5 & & 3 & 3 & \\
\hline May & 17 & 3 & 5 & 4 & 1 & 4 & & \\
\hline June & 22 & 6 & 4 & 3 & & 8 & 1 & \\
\hline Total & 133 & 23 & 45 & 30 & 4 & 20 & 10 & 1 \\
\hline
\end{tabular}

a) For instance, about the death of an author or the nomination of an author for a prize, but also book reviews.

b) Practical information about opening hours or problems at the library, but also about empty positions etc.

c) Pictures from events, but also pictures showing how it looks at the library right now.

d) Shared link from British newspaper about Virginia Woolf but combined with a question to the patrons.

e) Sami national day.

on. Even if the number of shares and comments was limited, these three posts succeeded in engaging the followers much more than all the other posts.

The post with by far the most likes (120) is shared content (an article from digi.no) informing about how all Norwegian books published before the year 2000

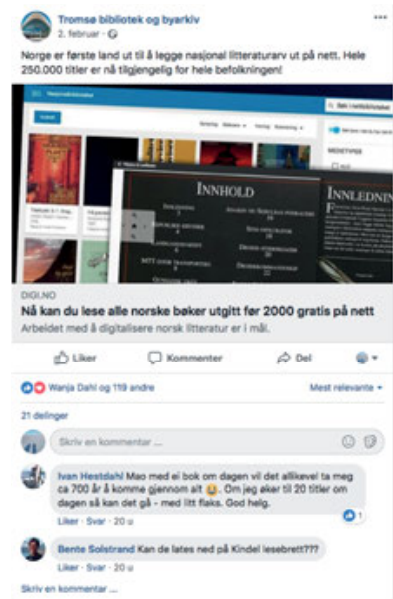

120 likes, 21 shares, 2 comments

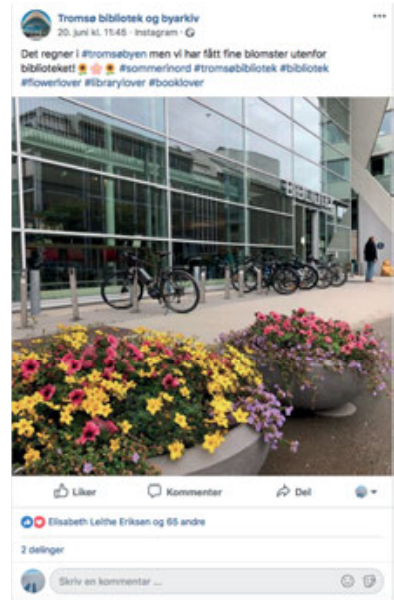

66 likes, 2 shares, no comments

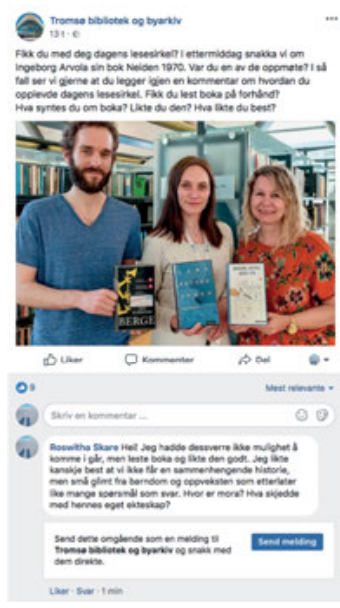

58 likes, 5 shares, 2 comments 
are accessible for free on the webpages of the National library of Norway - information that should be relevant and interesting for people interested in the library and reading. While Camarero et al. found that "external links which users need to click on seem [not] recommendable, since users prefer visual posts and short texts" $(2018,1129)$, this post did not only generate the most likes, but also a relatively high number of shares that contributes to the virality of the post and the library's Facebook page. One reason for this might be the content of the shared article, while another reason might be the way the library posts the article. The library not only posts the link, but also adds a short text that summarizes the content. The number of likes and shares indicates high popularity and a certain virality. There is nevertheless little user commitment with only two comments where one person is asking about practical issues while the other is pointing to the high number of books available online and how long it would take to read all these books. Neither the library nor the other users are reacting to these comments, not even on the practical question of whether these books can be downloaded to a kindle reader.

The post with 66 likes is about the summer weather in Tromsø. The photo used in this post is from the entrance of the library where flowers were planted. As pointed out by Camarero et al., the use of a picture might have "a positive impact on the number of likes" $(2018,1128)$. Even if the post reaches a certain popularity, it does not create content from the users or any virality. With regards to the topic of the post this is not surprising: there is not much to do about the weather, but the followers can express that they like the flowers or the image of the library together with the flowers by using the like option. Nevertheless, one might argue that the post works in connecting the library with its users and that the visitors can maintain a relationship with the institution by viewing the image of the library and by liking the post.

The third post presents an image of three persons with a book in their hands. The longer text explains that the library will start a new activity - a reading group - and how it will be organized. Users familiar to Troms $\emptyset$ public library will recognize that the picture is taken inside the main library. Some will also recognize the persons in the photo as librarians working there. Fifty-eight likes, five shares, and two comments indicate both popularity and virality, but little user engagement when it comes to creating own content. As in the case of the post with most likes, this post only generates two comments that express excitement about that initiative. There is no conversation between the library and its users or among the users about what to expect etc. 


\section{The Facebook Page of the Arctic University Museum of Norway (TMU)}

The FB-page of the Arctic University Museum of Norway (TMU) is followed by 7,632 persons (June 2019), a significant higher number of followers than the other two institutions in this study. The persons following the TMU might in addition to people living in Troms $\varnothing$ also be tourists that have visited or plan to visit Troms $\varnothing$ and the museum. In addition to FB, the museum is also present on Instagram $(1,883$ followers).

As for the library, the text of each post, the number of likes, shares, and comments were registered in an Excel document. As mentioned above, the total number of posts from TMU during these six months is higher than for the library, but here we can also observe the same tendency: a large part of posts are event announcements (60) and shared content (36).

Tab. 10.4: TMU - number of posts by categories

\begin{tabular}{lllllll}
\hline & $\begin{array}{l}\text { Number } \\
\text { of posts }\end{array}$ & $\begin{array}{l}\text { Status/ } \\
\text { activities }\end{array}$ & $\begin{array}{l}\text { Event announce- } \\
\text { ment/Shared } \\
\text { event }\end{array}$ & $\begin{array}{l}\text { Shared link/ } \\
\text { content/ } \\
\text { post/video }\end{array}$ & $\begin{array}{l}\text { Pictures/ } \\
\text { shared } \\
\text { albums }\end{array}$ & $\begin{array}{l}\text { "Fredags- } \\
\text { gløtt"c) }\end{array}$ \\
\hline Jan & 21 & 3 & 11 & 5 & 2 & \\
Febr & 30 & 5 & 12 & 6 & 4 & 3 \\
Mar & 38 & 2 & 18 & 12 & 3 & 3 \\
April & 19 & 3 & 7 & 4 & 1 & 4 \\
May & 21 & 5 & 7 & 4 & 1 & 4 \\
June & 22 & 5 & 5 & 5 & 2 & 5 \\
Total & 151 & 23 & 60 & 36 & 13 & 19 \\
\hline
\end{tabular}

a) For instance, Happy new year on January $1^{\text {st }}$, but also information about activities of the museum like exhibitions and collections or information about prizes won by employees.

b) Articles from the local newspapers (www.itromso.no; www.nordlys.no), from the university (uit.no), the Norwegian broadcaster NRK, forskning.no (about research in Norway), and forskerforbundet.no (the union most Norwegian researchers are organized in).

c) Every Friday an old photo accompanied by an explaining text is posted. In May there is one post called "Museumsgløtt"; the photo was not posted on a Friday, probably because of the many holidays in May.

The analysis of the posts led to five categories: status/activities, event announcement, shared content, pictures, and "Fredagsgløtt". While the first four categories can be compared to the library's activities on FB, "Fredagsgløtt" is a term coined by the museum itself for posts that combine old photographs with an explaining text, posted each Friday. The museum started in February 2018 with these posts 
on a regularly basis. "Fredagsgløtt" therefore is the only category with a given number of posts during the period studied here.

A little more than a third of all posts (57) had between 0 and ten likes, while another third (59) had between ten and 50 likes. Twenty-five posts had between 50 and 100 likes, while nine posts had considerably more likes, sharing, and also comments. Eight out of these nine posts had between 100 and 200 like, while one post was outstanding with 617 likes, 76 sharing and 137 comments. Five out of these nine posts with the most like included the one with over 600 likes which belongs to the category "Fredagsgløtt", published on Fridays.

I will in the following have a closer look on the three posts with most likes. Two of these three posts belong to the category "Fredagsgløtt", while the third one provides information on how to make a bee-hotel.

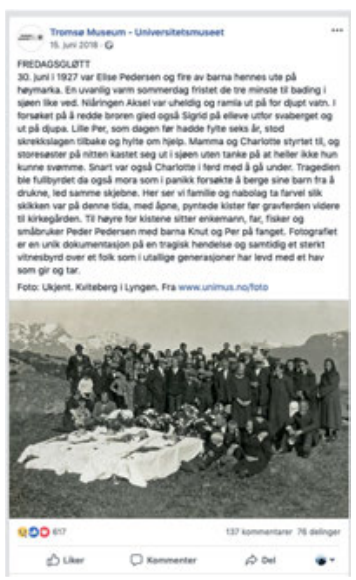

617 likes, 76 shares, 137 comments

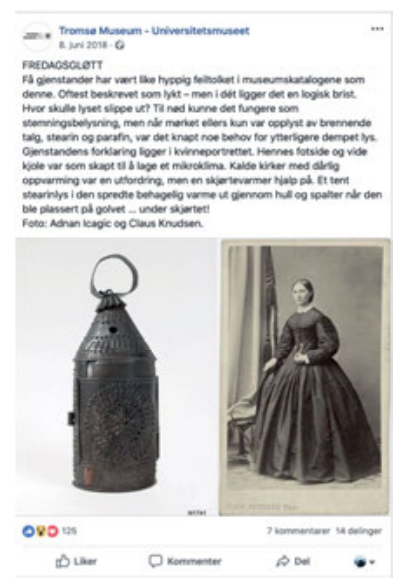

125 likes, 14 shares, 7 comments

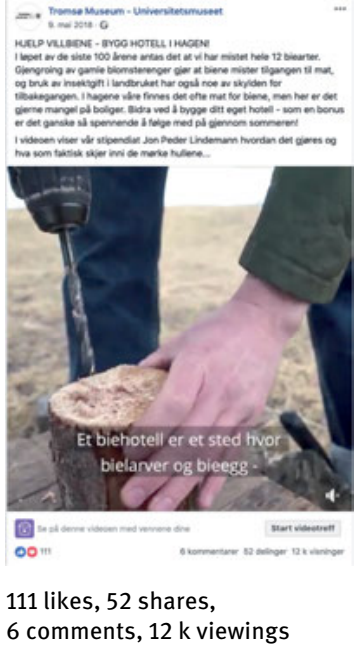

111 likes, 52 shares, 6 comments, $12 \mathrm{k}$ viewings

The post with by far most likes (617) presents an old photograph where family and neighbors are gathered around four open coffins. The accompanying text explains the tragical drowning accident that happened on a warm summer day in 1927. The name and age of the persons involved in the accident as well as the name of the place are mentioned in the text.

The high number of likes (617), shares (76), and comments (137) indicates not only high popularity but also high virality and user engagement. While Camarero et al. found that the "popularity of a post does not increase when its content increases (a longer post)" (2018, 1128), this post is actually an example with quite a long text, but all in combination with an image. The "creativity of said content 
(images and emotional tone)" (Camarero et al. 2018, 1128) seems to be the most important criterion for user engagement.

Although the content of the comments varies and some only demonstrate their feelings by posting an emoji, many of the comments are about the historical event, the persons in the photo etc. It seems that historical photos that the followers can relate to because of their geographical closeness and even familiarity with the persons in the photo create more engagement and user generated content that again contribute to the virality of the post, especially the post about the funeral which initiated a conversation between the followers of the page and also between the followers and the museum. Unlike many other posts that have comments, the comments on this post are not only articulating own thoughts but are also responses to the expressions of others. These responses transform the commentary field in a kind of meeting place for the persons involved and engaged in this historical event and create a kind of community for the time being.

While the post with the second most likes also belongs to the category of "Fredagsgløtt", combining historical images with an explaining text, the third post contains a video that shows how to build a bee-hotel. While the text invites the users to build a bee-hotel in order to help the bees find food and to survive, the video demonstrates how to build one. This post has many likes and shares and $12 \mathrm{k}$ viewings, but only six comments. Here we find people tagged in the commentary field, a way to draw other's attention to the content of the post, but not so much a way to engage in conversation with other people. This post also demonstrates that the content reaches a large number of persons but that most of them probably only watch the video without any need to express their thoughts about it.

\section{Perspektivet Museum on Facebook}

2,144 persons follow the Facebook page of Perspektivet museum (June 2019), the lowest number of all three institutions. The museum is also active on Flickr (395 followers) and Instagram (1,122 followers).

Even if Perspektivet museum has less posts during the first six months of 2018 (only three per week on average), the same tendency as for the other institutions is visible when analyzing the posts. Also, for Perpektivet museum the two categories of event announcements (23) and shared content (14) account for half of the total posts. The museum uses both pictures and videos to inform their followers about activities at the museum; videos are used more often here than the university museum.

The smaller number of posts - compared to the other two institutions studied here - can be explained by the size of the museum. The museum is probably not 
Tab. 10.5: Perpsektivet museum - number of posts by categories

\begin{tabular}{lllllll}
\hline & $\begin{array}{l}\text { Number of } \\
\text { posts }\end{array}$ & $\begin{array}{l}\text { Status/ } \\
\text { Activities/ } \\
\text { Exhibition }\end{array}$ & $\begin{array}{l}\text { Event announce- } \\
\text { ment/Shared } \\
\text { event }\end{array}$ & $\begin{array}{l}\text { Shared link/ } \\
\text { content }\end{array}$ & $\begin{array}{l}\text { Photos/ } \\
\text { shared } \\
\text { albums }\end{array}$ & Video \\
\hline Jan & 11 & 0 & 4 & 1 & 6 & 0 \\
Febr & 14 & 1 & 5 & 3 & 4 & 1 \\
Mar & 12 & 5 & 3 & 3 & 1 & 0 \\
April & 15 & 1 & 6 & 3 & 2 & 3 \\
May & 9 & 4 & 1 & 2 & 0 & 2 \\
June & 13 & 1 & 4 & 2 & 4 & 2 \\
Total & 74 & 12 & 23 & 14 & 17 & 8 \\
\hline
\end{tabular}

working with social media on a daily base, as there are periods with many posts and then periods with little or no activity. Forty-four posts, more than half of all posts, received between 0 and ten likes, 24 posts had between 11 and 30 likes and only five posts had between 31 and 50 likes. This might indicate less popularity and virality than the posts from the other two institutions. The post with most likes received 77 likes, three shares and five comments. Posts with photos and videos are the ones that receive most engagement, even if the numbers are smaller than for the "most popular" posts from TMU. As mentioned above, the Perspektivet museum does not post on Facebook on a daily basis. ${ }^{12}$ Some days they post several messages that seem to receive about the same numbers of reactions, which might indicate that fans who like one post also like all the other posts.

The post with most user engagement is a post about a product made by the museum. The post is in English, but the comments are in Norwegian, mostly expressing the wish for one of these toy bags. It also seems that the persons communicating with each other know each other already. The other two posts that created most user participation are photos from one of the events held at the open-air museum. The same person commented on both posts, expressing how much she liked that event.

12 Part of the museum is also an open-air museum situated outside the city center and some old buildings on the neighbor island. During the summer months many of the museum's activities take place in the open-air museum. 


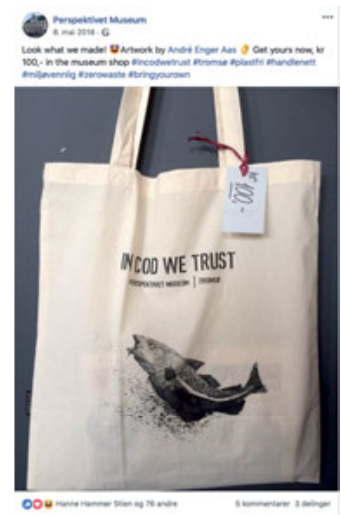

77 likes, 3 share, 5 comments

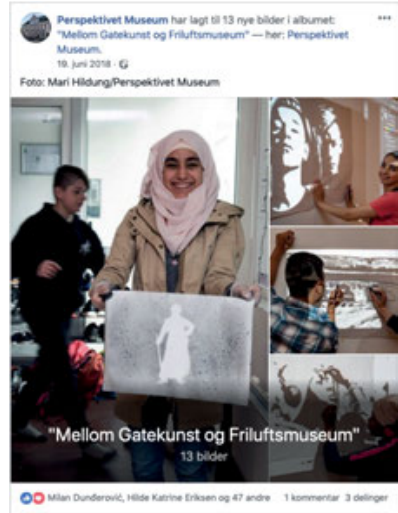

49 likes, 3 shares, 1 comment

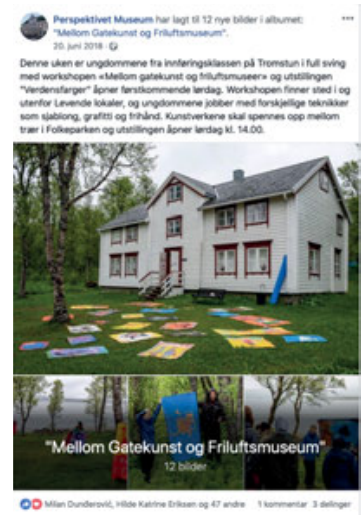

49 likes, 3 share, 1 comment

Even if the number of the museum's posts on Facebook is limited during these six months, this finding is also confirmed by Camarero et al.: a post's popularity increases when its content is presented "in a number of languages" $(2018,1128)$, and "the use of pictures [...] has a positive impact on the number of likes" (2018, 1129). "A greater total number of posts" - in the case of Perspektivet up to 4 posts on one day - reduces virality (per post)" $(2018,1129)$.

\section{Discussion of the Findings}

The comparison of the three institutions' Facebook appearance indicates many similarities: all three institutions post on a regular basis, but the frequency of posts is rather low. The posts usually combine text and images, with only Perspektivet museum using video on a more regular basis. Posts that announce events or share content are most frequent for all three institutions. Most of the posts have no or only very few likes and shares. Comments are not frequent and most of the comments are statements without any form for conversation or reaction to comments made by others. Only a few posts create a larger user engagement, not only in likes and shares, but also in the form of comments. Here the posts entitled "Fredagsgløtt" by the university museum are in an extraordinary position. Many of these posts are not only liked and shared, but create a conversation between the users and in some cases between the users and the museum, especially the one post about a tragic accident posted by the museum which has created by far the most likes, shares, and comments. The comments on that post actually also created a conversation between the followers involved and between the followers and the 
museum. This might suggest that the use of images (both still and video) is important, but even more important is emotional engaging content that connects the followers and the institution. As some of the posts of the Tromsø public library illustrate, it is not enough to ask a question to create a conversation: "At the post level, posting questions reduces virality. [...] if a [sic] organization is seeking users' active participation in its communications then the organization itself should also get involved in users' conversations” (Camarero et al. 2018, 1130).

The results from this case study seem to confirm that most Facebook users only read a post or watch an image without any need to get further engaged in the content of the post. It seems that most users are only engaged in activities that demand little commitment, such as liking and sharing of posts. While the numbers of likes and shares are indicators for a post's popularity and its virality, the number of comments might be an indication for the user's commitment. One might conclude that the users are - with the exception of the posts "Fredagsgløtt" by TMU - not very committed to these institutions, but this might only be true to some degree. From the outside it is impossible to know how many users actually read the posts, and whether they are engaged by the content or not. Since many of the posts are event announcements or contain practical information, they do not demand any kind of reaction or much engagement. This is in line with the findings by Capriotti and Losada-Díaz that Facebook often is used in "a traditional off-line one-way perspective [...], considering it as a mere tool that can be used to disseminate information about the institution and its activities, but not to stimulate interaction and two-way communication with their publics" $(2018,648) .{ }^{13}$ My own findings thus confirm what is established in other studies about the use of social media by LAMs and other organizations in the corporate world.

To meet patrons/ users where they are is one argument used by the institutions studied here to justify their presence on social media. Another argument, not explicitly mentioned, is announcing an event on Facebook is free compared to an advertisement in the local newspaper that must be paid for. ${ }^{14}$ The problem is still how to reach out to users and patrons. As far as I know, none of the institutions studied here have asked their patrons and users if they want the institution to be on Facebook or on other social media or what the users expect to find on social media. One might argue that institutions like public libraries and muse-

13 Similar findings were made by Ahorany 2012 and Lazzaretti et al. 2015.

14 Facebook is of course not for free and both the institutions and we as individual users are paying with information about ourselves and our information behavior. 
ums have to be present on social media because all others are. ${ }^{15}$ Nevertheless, it is not enough to be present on Facebook. The institutions not only need resources for posting, monitoring, and responding on social media; they also should have a clear strategy for what they want to achieve by their social media presence. In Norway, public libraries and most museums are non-commercial institutions financed by the public. Still, they depend on the number of visitors/ patrons to legitimate their existence and funding. It is therefore important to reach out to the public and to tell about activities and news. Social media can be seen as one tool to connect with the public and a place where visitors can maintain a relationship with the institution.

Discussions about the Internet and especially about Web 2.0 and social media platforms often stress their democratic potential, providing meeting places where user contribution, collective intelligence, reuse and remix (Jenkins 2006), but also empowerment and ownership have become buzzwords since the mid-2000s. Participation in terms of individuals becoming "creators and primary subjects" who communicate "effectively into the public sphere" (Benkler 2006, 213) is discussed as the Internet's democratizing potential leading to the emergence of a network public sphere (Benkler 2006, 272). While this might be true for user generated content on for instance wikis, blogs or YouTube, Facebook is obviously not the place for many of these activities, as most of the users are more or less passive consumers of the content presented by the institutions. ${ }^{16}$ Capriotti and LosadaDiaz conclude that "the museums analyzed [...] are not taking advantage of all the tools offered by Facebook as a means of interactive and dialogic communication" $(2018,647)$. The same could be said about the institutions in Troms $\varnothing$ analyzed here. This leaves the question unanswered of if users actually are interested in using social media platforms to communicate with each other or with the institution. As mentioned before, the large majority of FB-users are passive consumers not active contributors or even producers of content. If the institutions want to interact with their users by providing digital meeting places, for instance on FB, they have not only to use the opportunities provided by the social media platform, but also engage in a conversation with their patrons on a regular basis. It is obviously not enough to ask a question once in a while; a climate of dialogue, exchange

15 In the USA, "93\% of the largest libraries; 82\% of libraries serving between 25,000 and 499,999; $68 \%$ of libraries serving between 10,000 and 24,999 ; and $54 \%$ of the smallest libraries" (Hofschire and Wanucha 2014, 7) were on Facebook in 2012.

16 It would be interesting to look into commercial FB pages and the role of competitions and giveaways. Users seem to participate by writing a comment much easier when they can win something. However, these comments often are not creating any form for conversation but are only very short statements; often the company only asks for an emoji or the name of a person. 
and conversation has to be established day by day. The examples from the university museum's "Fredagsgløtt” indicate that a conversation between users and between the institution and the users is possible as long as the content is personally engaging. It seems that posts consisting of old photographs and emotionally engaging stories are the ones that engage followers the most, often also because of the follower's geographical closeness to the place and the persons involved. The use of images and videos, especially from events where followers can see and watch themselves or persons they might know, seems also to create a high user engagement in shares and likes.

There might be different reasons for people to follow the library or a museum on Facebook. Getting updates and reminders about events might be one important reason, while meeting other people might be less important in an online environment. Nevertheless, the Facebook pages of institutions like public libraries and museums are part of the public sphere, even if these digital public spheres are small and produce only little user participation. These "weak publics" (Fraser 1992, 134) exist beside all the other publics the institutions create both by their events and by being open and including institutions where people can meet and talk to each other, either planned or by chance.

\section{References}

Aharony, N. "Facebook Use in Libraries: An Exploratory Analysis”. Aslib Proceedings: New Information Perspectives, 64, no. 4, 358-372, 2012. https://doi.org/10.1108/ 00012531211244725.

Badell, J.-I. “Museums and Social Media: Catalonia as a Case Study”. Museum Management and Curatorship, 30, no. 3, 244-263, 2015. https://doi.org/10.1080/09647775.2015. 1042512.

Benkler, Y. The Wealth of Networks. New Haven, CT: Yale University Press, 2006.

Capriotti, P. and J.-C. Losada-Díaz. "Facebook as a Dialogic Communication Tool at the Most Visited Museums of the World". El Profesional de La Información, 27, no. 3, 642-650, 2018. https://doi.org/10.3145/epi.2018.may.17.

Carlsson, H. "Researching Public Libraries and the Social Web, 2006-2012". Journal of Documentation, 71, no. 4, 632-649, 2015. https://doi.org/10.1108/JD-03-2014-0046.

Camarero, C., M.-J. Garrido, and R. San Jose. "What Works in Facebook Content Versus Relational Communication: A Study of their Effectiveness in the Context of Museums". International Journal of Human-Computer Interaction, 34, no. 12, 1119-1134, 2018. https://doi.org/10.1080/10447318.2017.1418475.

Fraser, N. "Rethinking the Public Sphere: A Contribution to the Critique of Actually Existing Democracy”. In Calhoun, C. (ed.), Habermas and the Public Sphere, pp. 109-142. Cambridge, Massachusetts, and London, England: The MIT Press, 1992. 
Hofschire, L. and M. Wanucha. "Public Library Websites and Social Media”. Computers in Libraries, 34, no. 8, 4-9, 2014. https://search.proquest.com/docview/1625138478? accountid=17260.

Jenkins, H. Convergence Culture. Where Old and New Media Collide. New York and London: New York University Press, 2006.

Jørgensen, G. “Den vanskelige dialogen. Om universitetsmuseenes praktiske utfordringer i møtet med web 2.0-samfunnet”. Nordisk Museologi, 1, 81-97, 2011. http://dx.doi.org/10. $5617 / \mathrm{nm} .3147$.

Kidd, J. “Enacting Engagement Online: Framing Social Media Use for the Museum”. Information Technology \& People, 24, no. 1, 64-77, 2011. https://doi.org/10.1108/ 09593841111109422.

Kidd, J. Museums in the New Mediascape. Transmedia, Participation, Ethics. London and New York: Routledge, 2016. https://doi.org/10.4324/9781315596532.

Kommunal- og moderniseringsdepartementet. "Digital agenda for Norge. IKT for en enklere hverdag og økt produktivitet. (Meld. St. 27 (2015-2016))”. Technical report, Departementet, Oslo, 2015. https://www.regjeringen.no/no/dokumenter/meld.-st.-2720152016/id2483795/.

Kulturdepartementet. "Nasjonal strategi for digital bevaring og formidling av kulturarv. (St.meld. nr. 24 (2008-2009))”. Technical report, Departementet, Oslo, 2008. https: //www.regjeringen.no/no/dokumenter/stmeld-nr-24-2008-2009-/id555254/.

Kulturdepartementet. "Framtidas museum - Forvaltning, forskning, formidling, fornying. (St.meld. nr. 49 (2008-2009))”. Technical report, Departementet, Oslo, 2008. https: //www.regjeringen.no/no/dokumenter/stmeld-nr-49-2008-2009-/id573654/.

Lazzeretti, L., A. Sartori, and N. Innocenti. "Museums and Social Media: the Case of the Museum of Natural History of Florence". Int Rev Public Nonprofit Mark, 12, 267-283, 2015. https://doi.org/10.1007/s12208-015-0136-5.

Mathiasson, M. and H. Jochumsen. "Researching Public Library Programs Through Facebook Events: A New Research Approach”. Journal of Documentation, 75, no. 4, 857-875, 2019. https://doi.org/10.1108/JD-08-2018-0137. 